\title{
AGAINST THE REVISIONARY POLITICAL READING OF KELSEN*
}

EN CONTRA DE UNA LECTURA POLÍTICA REVISIONISTA DE KELSEN

\author{
Mario GARCÍA BERGER ${ }^{* *}$
}

\section{Resumen:}

El principal objetivo de este trabajo es rechazar la interpretación no-estándar acerca del valor de la teoría pura del derecho propuesta por Lars Vinx y, en menor medida, por David Dyzenhaus. De acuerdo con esta lectura, el mérito de la explicación kelseniana de la normatividad jurídica reside en su conexión con la filosofía política del propio Kelsen. Esta tesis se fundamenta en la idea de que la teoría pura falla en su intento de explicar la naturaleza del derecho, de modo que tiene que renunciar a su pretendida cientificidad y pureza. Mi propósito es mostrar que ambas ideas están equivocadas y señalar una forma de entender el nexo entre la teoría pura y las ideas políticas de Kelsen que se apega a su concepción de la ciencia jurídica. También propongo una explicación de la relación entre ciencia jurídica, democracia, estado de derecho y principio de legalidad que incorpora elementos presentes en Kelsen.

\section{Palabras clave:}

Teoría pura del derecho, normatividad jurídica, estado de derecho, democracia, legalidad.

\section{Abstract}

The main objective of this paper is to reject the non-standard interpretation

* Artículo recibido el 7 de marzo de 2019 y aceptado para su publicación el 11 de marzo de 2020.

** Doctor en Filosofía por la UNAM, adscrito a la Universidad Autónoma de la Ciudad de México (UACM), correo: mgberger@live.com, ORCID: https://orcid.org/00000001-5320-3088. 


\section{MARIO GARCÍA BERGER}

of the merit of the pure theory of law proposed mainly by Lars Vinx and, in a lesser extent, by David Dyzenhaus. According to this reading, the value of the kelsenian explanation of the normativity of law lies on its connection to Kelsen's political philosophy. This tenet is based on the idea that the pure theory fails in its attempt to explain the nature of law, so it has to give up its scientific status and its purity postulate. My purpose is to show that both ideas are misguided and to suggest a way to understand the connection between the pure theory and Kelsen's political ideas more faithful to his conception of legal science. I also propose a relation between legal science, democracy, the rule of law and the principle of legality that incorporates elements present in Kelsen.

\section{Keywords:}

Pure Theory of Law, Legal Normativity, Rule of Law, Democracy, Legality. 
SUMmARY: I. Introduction. II. The Standard Interpretation of Kelsen. III. The Revisionary Political Reading of Kelsen. IV. Some Considerations on Vinx's Reading of Kelsen. V. Conclusions. VI. References.

\section{INTRODUCTION}

Kelsen conceived, at least in his classical phase, ${ }^{1}$ his pure theory of law as the result of applying the Kantian transcendental method, in its regressive form employed by the Marburg Neo-Kantians, to the science of law. To the question how the cognition of the law is possible, Kelsen responds that it is the basic norm, by ascribing legal meaning to certain social facts, which makes their legal interpretation available. Thereby, the object of the science of law is epistemologically constituted. Thus, Kelsen saw his own work as the transcendental deduction of those concepts (categories) from which the legal interpretation of human conducts is theoretically construed. This epistemological self-comprehension of the pure theory is manifested in various places. ${ }^{2}$ Despite Kelsen's straightforward declaration of the motives that underlie his theoretical enterprise, there are alternative readings of the pure theory. Some of these interpretations, that we can call "practical", greatly deviate from the standard (epistemological) interpretation. They are basically of two types: moral and political. The moral reading is exemplified by Carlos Nino's explanation of Kelsen's concept of validity in terms of justifiability and Joseph Raz's ascription to Kelsen of a justified norma-

1 For a periodization of Kelsen's work see, among others, Stanley, Paulson, "Four Phases in Hans Kelsen's Legal Theory? Reflections on a Periodization", Oxford Journal of Legal Studies, 18; Eugenio, Bulygin, "An Antinomy in Kelsen's Pure Theory of Law", Ratio Juris, 3 and Carsten, Heidemann, "Die reine Rechtslehre im Lichte des kritischen Rationalismus" Ratio Juris 18.

2 Hans Kelsen, Teoría general del estado (first published in German 1925, trans. by L.L Lacambra, Editora Nacional 1965), p. VIII; Hans Kelsen, “Un inédit de Kelsen concernant ses sources kantiennes" Droit et Société 7 327-328; Hans, Kelsen Problemas capitales de la teoría jurídica. Desarrollados con base en la doctrina de la proposición jurídica (first published in German 1923, trans. by W Roces, Porrúa 1987) L. 
tivity. ${ }^{3}$ The most direct antecedent of the political interpretations is the work of Uberto Scarpelli. ${ }^{4}$ Their central tenet is that the merit of the pure theory can only be appreciated when it is connected with Kelsen's political views. Even though Scarpelli focused on the relations between legal positivism and the modern state, his conclusions can be applied to Kelsen. A more recent full-fledged attempt to reevaluate the value of the pure theory through its relation to an ideal political system is that of Lars Vinx and, in a lesser degree, of David Dyzenhaus. ${ }^{5}$

The moral and the political readings of the pure theory share the idea that Kelsen's epistemological programme is doomed to failure. However, while the former tends to reformulate key Kelsenian concepts to provide them with a moral justification, the latter concentrates, for instance, on the nexus of the pure theory with the rule of law, political liberalism or the principle of legality. Vinx and Dyzenhaus have put forward the thesis that Kelsen's theoretical edifice is defensible only if it is connected with the political project that lurks behind his reflections on democracy, the rule of law and the principle of legality. For Vinx, the merit of the pure theory is its con-

3 Carlos Nino, La validez del derecho (Astrea 1985); Carlos Nino, "Some Confusions sorrounding Kelsen's Concept of Validity" in Stanley Paulson and Bonnie Litschewski (eds), Normativity and Norms. Critical Perspectives on Kelsenian Themes (Clarendon Press 1998); Joseph Raz, "The Purity of the Pure Theory" in Stanley Paulson and Bonnie Litschewski (eds), Normativity and Norms. Critical Perspectives on Kelsenian Themes (Clarendon Press 1998); Joseph Raz, "Explaining Normativity. On Rationality and the Justification of Reason" in The Authority of Law. On the Theory of Value and Action (OUP 1999). Juan Ruiz Manero holds that Kelsen is an ethical positivist. He adds that if we give preference to practical over epistemological interests when interpreting the pure theory, it appears in a better light, as a more coherent and more meaningful theory. Juan Ruiz, Manero, "Cincuenta años después de la segunda edición de la Reine Rechtslehre. Sobre el trasfondo de la teoría pura del derecho y sobre lo que queda de ella", 33 Doxa 40-41.

4 Uberto, Scarpelli, ¿Qué es el positivismo jurídico? (first published in Italian 1965, trans. by J. Hennequin, Cajica 2001).

5 Lars Vinx, Hans Kelsen's Pure Theory of Law (OUP 2007); David Dyzenhaus, "Legal Theory in the Collapse of Weimar. Contemporary Lessons?" in The American Political Science Review 91; David Dyzenhaus, Legality and Legitimacy: Carl Schmitt, Hans Kelsen, and Hermann Heller in Weimar (OUP 1999); David Dyzenhaus, Hard Cases in Wicked Legal Systems: Pathologies of Legality (OUP 2010). 
tribution to the explanation of legal legitimacy. ${ }^{6}$ This non-standard reading implies three controversial theses: (1) the pure theory does not explain the normativity of law; (2) given such failure, its value can only be appreciated if the theory is linked with Kelsen's political philosophy; and (3), consequently, it must resign to its scientific aspiration and to its purity postulate. I will try to show that the arguments in favor of these theses are unconvincing and I shall offer an account of the nexus between the pure theory and Kelsen's conception of democracy, the rule of law and the principle of legality that is in accordance with the epistemological thrust of the pure theory. I will focus on Vinx's stance since he has recently formulated a fullblown political approach to Kelsen. Though in a lesser extent, some aspects of Dyzenhaus' less-developed conceptual framework shall also be analyzed.

\section{THE STANDARD INTERPRETATION OF KELSEN}

This reading of Kelsen has its roots on the influence the Neo-Kantian movement had on the epistemological framework of the pure theory of law. In a nutshell, this orthodox interpretation conceives, along the lines of Kant's philosophy and the reformulation the NeoKantians of the Marburg school made of it, that the pure theory has a constitutive role since it provides the $a$ priori concepts that explain the possibility of legal science, which in turn creates its object of study, the law, from a conceptual perspective. In other words, legal science makes possible the legal interpretation of human actions. In this section I shall expose the main thrust of this reading of Kelsen which centers on the grounding function that the basic norm (BN henceforth) plays with respect to the normativity of law.

I want to stress two theses from Hermann Cohen that had a big impact on the doctrine of the basic norm: that the ultimate ground of every science is a hypothesis and that the method of cognition determines its object.

6 Lars, Vinx (n 5) 3. 
In his famous letter to Renato Tréves, Kelsen recognizes that the BN derives entirely from the method of the hypothesis developed by Cohen. In this sense it is affirmed that the object of study of science is created from a logical origin. ${ }^{7}$ But what is a hypothesis in Cohen's philosophy? A concept formed by the transcendental consciousness that serves to explain a set of phenomena in reference to a law. The notion of explanation according to a law has to do with the Kantian idea that the cognitive process consists in the reduction of pluralities to unities. This is done by the synthetic a priori judgments, which unify, by means of the categories of the understanding, the diversity of our experience of physical phenomena. In the same vein, for the Marburg Neo-Kantians, cognition explains multiplicities by reducing them to a single nomic unity or legal principle. Cohen expresses this methodological maxim by means of his judgement of the origin (Urteil des Ursprungs), which means that nothing is given to cognition if it is not capable of being reduced to an ultimate grounding. As he puts it, "nothing can be regarded as given to the pure thought; also the given must create itself". ${ }^{8}$ An example of a Cohenian hypothesis postulated by legal science is the juridical person, since its function is to impute certain legal facts to a single point. This point of imputation (Zurechnungpunkt) is not metaphysical but normative because it consists of norms. ${ }^{9}$

On the other hand, the thesis that the direction of thought determines its object arises from the Neo-Kantian idea that reason has three main uses. It is employed theoretically when its object of enquiry is the natural world, that is, the possible experience subjected to the spatiotemporal causality. The practical use gets manifested when the object of reflection is men's free will portrayed in the sphere of moralilty and of law. Thirdly, reason has an aesthetic use when what is at stake is the explanation of the pure sentiment displayed in the science and history of art. The transcendental method

7 See above note 2 .

8 Hermann Cohen, Logik der Reinen Erkenntnis (Bruno Cassirer Verlag 1922) 101. My translation.

9 Manfred, Pasher, "Hermann Cohens Einfluss auf Kelsens reine Rechtslehre" 23, 4 Rechtstheorie 450-452. 
demands, for each of these directions (cultural facta), the deduction of their corresponding legal grounding (Rechtsgrund), according to which these human productions become a problem for scientific consideration. The deduction of the a priori categories that make science, law and morality, and the science of art possible, determines what the objects of such disciplines are.

For Kelsen, the theoretical origin of the normativity of law that allows us to conceive any set of human conducts as the creation of a legal norm is the BN. The Grundnorm has the same methodological and explicative function as Cohen's hypothesis, since it is the epistemological presupposition that lies at the summit of legal cognition. As can be appreciated, the parallelism between the two doctrines is crystal clear. The basic norm and the Cohenian hypothesis play a similar role, namely, to explain systematically the set of phenomena that are brought into their consideration, thereby producing a meaningful whole. The fact that Kelsen calls his BN hypothetical underscores this similarity. There is a passage from Cohen that leaves no room for doubt as to where the doctrine of the basic norm comes from:

Sometimes the hypothesis is the beginning and the grounding of the theory; also, it is not more than a supposition.... All theory, all law, cannot have another ground than the one established by the grounding. And there cannot be another certainty and security different from that of the grounding. [...The hypothesis] is referred to the concordance with phenomena, to the result it can obtain for the coherent explanation of phenomena and problems. If it does not achieve this result, then it has not been proven like a hypothesis... The hypothesis, to the extent it fulfills its concept, has certainty and security. There does not exist any other security. ${ }^{10}$

In a nutshell, Cohen's core claim is that the grounding of all cognition can only be a theoretical hypothesis or origin. And this is precisely the function the BN has with regard to legal science. Thus, the pure theory can be conceived as the result of applying, to what

10 Hermann Cohen, Ethik des reinen Willens (Georg Olms Verlag 2002) 98. My translation. 
Kelsen calls dogmatic jurisprudence, the Cohenian method of the hypothesis. As Ulises Schmill has pointed out, Kelsen, in his early stages, names the BN Ursprungnorm, in clear reference to Cohen's concept of the origin. ${ }^{11}$ Here, the grounding of cognition is not ontological but methodological. What founds cognition is its method, not some sort of reality we can directly access.

Within this framework we can read Kelsen's thesis that law is a conceptual creation of legal science in the sense that the latter provides us with the theoretical tools necessary to give legal meaning to what otherwise would only be human actions interpreted naturalistically, say, in terms of causes and effects. This tenet is formulated in some works of Kelsen's classical phase. Thus, in a passage taken from the Pure Theory of Law of 1953 he states that:

We can thus state simultaneously that the rules of law (règles de droit) are judgments formulated by legal science and that the object of such a science is constituted by legal norms. Here there is no contradiction. Without a doubt, one can consider that the norms created and applied within the framework of a legal system have the character of legal norms only if it is ascribed to them by legal science. It is the role of this science to attribute to certain acts the objective meaning of legal norms. But this does not prevent us from stating that legal norms form the object of legal science or, what is the same, that law is a system of norms. This definition is in full accord with Kant's theory according to which knowledge constitutes or creates its object, for what is in question here is an epistemological creation and not something created by man's work in the sense in which the lawmaker creates a law. In the same way, natural phenomena which are the object of causal science are only created by it in a purely epistemological sense. ${ }^{12}$

The science of law creates the legal order as a consistent and unitary system. When jurists interpret the legal materials produced by the activity of, say, legislators, they intend to construct a meaning-

11 Ulises Schmill, 'Algunas influencias de Hermann Cohen en Hans Kelsen', 21 Isonomia 149-153.

12 Hans, Kelsen, Introduction to the Problems of Legal Theory (first published in German 1934, trans. by B. Litschewski and S. Paulson, Clarendon Press 1997) 57. 
ful and rational whole out of these materials. This requirement, as Kelsen affirms, is imposed by the fact that science aims to provide a systematic and unitary explanation, free from inconsistencies, of the phenomena that constitute its object of enquiry. In the Pure Theory of Law of 1960 he calls the attention to the following parallelisms:

Just as the chaos of sensual perceptions becomes a cosmos, that is, "nature" as a unified system, through the cognition of natural science, so the multitude of general and individual legal norms, created by the legal organs, becomes a unitary legal system, a legal "order," through the science of law. But this "creation" has a purely epistemological character. ${ }^{13}$

That legal norms are created by the science of law means that only this discipline explains how it is possible to confer upon the prescriptive acts of an authority an objective normative meaning, since these acts in themselves just have the subjective meaning of norms.

Kelsen's approach to legal science is also clearly influenced by Cohen's thesis that the method of cognition (the direction of thought) determines its object. The early-twentieth-century concept of science demands, according to Kelsen, that legal science be autonomous from other disciplines, specially sociology, thereby demarcating the normative sphere from that of facts. In like manner, it has to be pure, that is, value-free and content-independent. This latter feature means that the ultimate grounding of science should be formal, a theoretical assumption, which in the case of legal science entails that the law is defined in terms of certain formal characteristics regardless of its content. The basic norm states how coercion is to be applied within a legal order. It is the "original" empowerment that endows the first historical makers of the law with the faculty to do so. But the BN does not establish the content of the law to be created; it only starts the process of norm creation, which makes it a formal principle. In this way, the pure theory of law assumes, prior to explaining the fundamental legal concepts, a characterization of what the law is. The normative character of legal science is based

13 Hans Kelsen, Pure Theory of Law (The Lawbook Exchange 2009) 232. 
on the distinction between the world of is and the world of ought, which Kelsen takes from the Neo-Kantian division between the natural sciences (Naturwissenschaften) and the cultural sciences (Kulturwissenschaften). Each kind of discipline has its own characteristic method. In the former the specific connection of events of the natural world is expressed by the principle of causality, whereas in the case of the science of law, one of the cultural disciplines, the legal proposition expresses the connection between two events-the illicit and the sanction - that are bound together in the norm through the principle of imputation, the Kelsenian Sollen. As the methodological form of natural laws and legal propositions springs from two different principles, legal norms cannot be conceived naturalistically. Therefore, the normativity of law has, for Kelsen, a purely transcendental/epistemological character. It refers to the specific link that binds together two events in the legal norm. ${ }^{14}$

Under Kelsen's epistemological/constitutive self-comprehension of his theory, its merit is to be evaluated according to its success in achieving the systematization of legal norms. Accordingly, the value of the theory is not dependent on any moral or political aim, it is purely epistemological. It is worth noting that the alleged constitutive character of the pure theory has been challenged, among others, by Stanley Paulson who has held that Kelsen's attempt to produce a conclusive argument to prove the unicity of his explanation fails, with the consequence that it has to renounce to its transcendental aspirations and find its place among other positivistic accounts of law. ${ }^{15}$

14 In this sense, I think the alternative interpretations of this concept that have been proposed in terms, for example, of a justified normativity introduce a moral element alien to Kelsen's own comprehension of his theory. See above note 3.

15 Stanley Paulson, "The Great Puzzle: Kelsen's Basic Norm” in Luís Duarte d'Almeida, John Gardner and Leslie Green (eds), Kelsen Revisited. New Essays on the Pure Theory of Law (Hart Publishing 2013) 49-52; Stanley Paulson, "A Justified Normativity Thesis in Hans Kelsen's Theory of Law? Rejoinders to Robert Alexy and Joseph Raz" in Matthias Klatt (ed), Institutionalized Reason: The Jurisprudence of Robert Alexy (OUP 2012), 71-78; Stanley Paulson, Facultad, responsabilidad y la teoría pura del derecho. Aspectos de una reconstrucción de acuerdo con la escuela Neo-Kantiana de Marburgo (Fontamara 2014) 103-106; Stanley Paulson, "On the Puzzle Sorrounding Hans Kelsen's Basic Norm" 13 Ratio Juris 279-284. 
AGAINST THE REVISIONARY POLITICAL...

\section{The Revisionary Political Reading of Kelsen}

\section{The Pure Theory and the Rule of Law. The Identity of Law and State}

Vinx's central idea is that Kelsen's political stance is a corollary of his conception of law. According to him, there is an internal or conceptual link between these two threads of Kelsen's work. Thereby, his conception of legal norms is not an isolated theoretical exercise to be assessed by its logical and methodological consistency. On the contrary, the main merit of this conception is its role in achieving democracy, the rule of law and the principle of legality. The relation between the pure theory and these political/moral aims is instrumental in nature, since this theory is the most effective mean to attain such goals.

Kelsen defines the rule of law in the following terms:

By the rule of law the principle is understood that the administrative and the judicial functions of the state should be determined so far as possible by preestablished general norms of law, so that as little as possible discretionary power is left to the administrative and judicial organs; freedom is thus guaranteed because arbitrary government is avoided. ${ }^{16}$

Though I will get back later to this characterization of the rule of law, it has two key elements: the activity of state organs is ruled by pre-established general norms and, consequently, their discretionary powers are so reduced.

According to Vinx, a conception of law helps to bring about the rule of law if it does not impose too many constraints on the possibilities of attaining it. A thesis that facilitates the rule of law is the identity of law and state, whose moral/political purpose is to legally bind the state power to protect individuals from its arbitrary application. Contrary to what Kelsen holds, such identity would not be the result of theoretical considerations, but the outcome of political ones, which have to be the basis for its defense. ${ }^{17}$ Instead, the dualist

16 Hans, Kelsen, "Foundations of Democracy" 66, 1, 2 Ethics p. 77.

17 Lars, Vinx (n 5) p. 22. 
view that conceives that law and state are separate realities, ${ }^{18}$ which involves the preeminence of the political sovereign over the legal order and the possibility of illegal state acts, sets limits on the rule of law using ideological arguments in scientific disguise. ${ }^{19}$ Later on we shall see that a similar movement from a descriptive-explanatory conception of legal science to the domain of normative ideals takes place in Vinx's interpretation of Kelsen's basic norm.

For Vinx, the identity of law and state means that the latter cannot illegally act, since the decisions of state organs do not constitute valid norms if they exceed the limits of their authority. This authority is subject to procedural and content dispositions. In consequence, the Kelsenian legality has a substantive character, for some norms impose restrictions on the possible content of other norms. Vinx affirms that the fact that the principle of legality implies that all state acts are legal:

must not be understood as an endorsement of the arbitrary and unlimited power of those who claim to act in the state's name. It is directed against the view that an act which falls short of perfect legality is valid, and hence binding on subjects, since it is still attributable, despite its imperfect legality, to the state. ${ }^{20}$

The thesis of the identity between law and state is compatible with the fact that the standards of legality that govern the attribution of acts to the state can be weak, because even in this scenario no state organ can, unilaterally, ignore the rules that set limits on its authority. ${ }^{21}$

The appeal of the pure theory is that its explanation of legal normativity is more congenial to the ideal of the rule of law, of democracy, and of the principles of constitutionalism than the dualism between law and state. If the ideal of the rule of law encompasses

18 Hans Kelsen, "Foundations of Democracy"; Hans, Kelsen, "Forma de estado y vision del mundo" (first published in German 1933, trans. by G Payás) in Oscar Correas (ed), El otro Kelsen (Ediciones Coyoacán 2003).

19 Lars Vinx (n 5) 16.

20 ibid 85-86.

21 ibid 211. 
'democratic procedures of legislation and a commitment to constitutional protections against the tyranny of a majority', the pure theory contributes to its realization because its conception of legal normativity 'aligns with the normative aim to subject organs of state as fully as possible to legal constraints against arbitrary exercises of power'. Vinx acknowledges that his reading of Kelsen fails to preserve the ideological neutrality that was one of Kelsen's desiderata. ${ }^{22}$

\section{The Basic Norm Reformulated}

Given the doctrine of the basic norm is one of Kelsen's central tenets, it is inevitable to ask for its contribution to the ideal of the rule of law. It is said that, in order to answer to the theoretical anarchist that denies the normativity of law, Kelsen must explain what justifies the presupposition of the basic norm and the acceptance of the authority it grants to the law. Here again we have the same movement from a descriptive-explanatory standpoint to a teleological view that we observed in Vinx's treatment of the thesis of the identity between law and state. In this case the justification of the basic norm does not reside in its theoretical role but in the contribution legality makes to the legitimacy of political power. ${ }^{23}$

In this way, for Kelsen, the normativity of law would emerge from his interest to explain the so-called legitimate state. Therefore, the presupposition of the basic norm makes sense only if we can say that the legal order it founds employs the coercive force in a socially justified manner. Vinx is crystal clear to this respect: 'To presuppose a basic norm, in short, is to postulate that exercises of coercive force that take place under the authorization of that basic norm are, in some sense and to some extent, morally justified.'. And some paragraphs after:

The pure theory contains a genuinely normative strand of thought not based on the implausible idea that the basic norm is needed to

22 ibid 17.

23 ibid 56.

24 id 
establish the possibility of the cognition of the law as an actual social practice. According to this strand, the presupposition of a basic norm is needed not to allow us to recognize law from a descriptive point of view but rather to make sense of what Kelsen takes to be its normative aspirations. ${ }^{25}$

Without further elaboration and just saying that it is an implausible idea, Vinx dismisses the grounding function of the normativity of law that Kelsen ascribes to the basic norm. Instead of this constitutive role that creates the law as the object of legal cognition, Vinx attributes the basic norm a justificatory or legitimizing function: 'To distinguish Kelsenian legal normativity clearly from substantive justice, I will from now on refer to the normativity a basic norm attributes to all norms that have membership in a legal system as legitimacy.26

Here legal normativity is distinguished from substantive justice. However, Vinx makes a methodological mistake when he equates the concept of normativity, that in Kelsen has a theoretical meaning, with the notion of legitimacy. Such a reading has neither textual nor contextual support in Kelsen's oeuvre. Vinx himself recognizes that the term legitimacy has no place in the pure theory and that Kelsen rejects the idea that the law can have legitimating effects on political power. ${ }^{27}$

\section{Legality and Legitimacy}

Legitimacy, the moral justification or the normative aspirations of a legal order are related, on the one hand, to the state's claim to obedience and, on the other, to the motives individuals have to obey the law. Put it in other words, the state claims obedience and citizens find reasons or not to comply. From the scientific perspective of the pure theory, any legal system possesses some degree, tough minimal, of legitimacy (de facto legitimacy), that can be increased if certain features of legality are strengthened: 'the impartial admin-

25 ibid 57-58.

26 ibid 59.

27 id 
istration of the law, the democratic creation of general legal norms, and the protection of individual and minority interests by formal constitutionalism'28.

In the ideal scenario, the legality of state acts is a sufficient reason for reasonable persons to accept that legal norms bind everyone ( $d e$ jure legitimacy). Here again Vinx expresses his moral/substantive conception of the basic norm:

The act of presupposing a basic norm, hence, is a way of expressing allegiance to the ambition of creating what I will call a utopia of legality. Legal science can justifiably abstract from all sources of justification other than legality and pretend, so to speak, that legality fully justifies acts of state as long as the hope for this utopia is reasonable. ${ }^{29}$

It is interesting to point out how the epistemological significance of the act of presupposing a basic norm is here metamorphosed into an act of allegiance to the law, thereby contradicting the methodological premises of the pure theory.

The utopia of legality condenses the desirable situation in a constitutional system:

in which the legality, in the non-trivial sense of the term, of an act of state that enacts or executes a legal norm is ordinarily sufficient to make that norm (or act of execution) fully legitimate, to constitute a duty on the part of the subjects of the law to defer to and obey it. ${ }^{30}$

In the utopia of legality legal legitimacy can always substitute other reason to obey the law such as the belief in the substantive virtues of the acts of the state, the trust in the moral integrity of the rulers or in their practical expertise. This makes possible 'the peaceful coexistence between morally divided groups in a pluralistic society. ${ }^{31}$

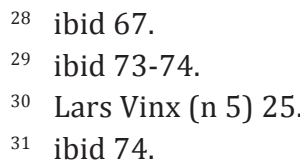


In this way, the state's power is compatible with the government of the law and is at odds with the government of men. If the appeal to legality made by the state to support its claim to obedience is 'to carry significant weight, there have to be legal standards that go beyond bare and uncontroversial formal means of identifying authoritative directives. There have to be laws, ideally constitutional laws, that, to some extent, guide or constraint exercises of power.'32 Thus, the legality of norms has a nontrivial normative meaning. For Dyzenhaus, the fundamental rights and freedoms of a constitution have to be protected from simple majorities if we are to secure the stability of the political system. ${ }^{33}$

From the nexus between the pure theory and Kelsen's political philosophy that Vinx tries to fix it can be deduced that the former is not positivist in three important respects: it establishes a necessary connection between legality and legitimacy; it can found duties of obedience to law and it holds that legality is the only source of de jure legitimacy of public power. These three claims depend on the ideal of a utopia of legality. This is the reason why 'Kelsen's pure theory of law cannot be classified as a descriptive-explanatory theory on the methodological level. It forms part of a political philosophy'. ${ }^{34}$

In consequence, Kelsen's purity postulate has to be reformulated. What is in need of purification would be the tendency that stands in the way of a utopia of legality: that of thinking that any attribution of justified normativity to the law must be either ideological or be based on a substantive theory of political justice. On the contrary, such attribution can only be justified if 'a positive legal system can come to realize values internal to positive legality, by protecting social peace in a way compatible with a reasonable person's claim to freedom.' ${ }^{35}$ A legal order grounds its normativity to the extent it takes care of these values.

One of the corollaries of Vinx's interpretation of the pure theory is the weakening of Kelsen's thesis about the separation between

32 ibid 210.

33 David Dyzenhaus, Legality and Legitimacy, .

34 Lars Vinx (n 5) 215.

35 ibid 216. 
law and morality. According to Vinx, this tenet makes sense only if it is understood as the independence of legal legitimacy from moral evaluations of the law. So interpreted, the claim would not amount to a denial of any necessary relation between law and morality ${ }^{36}$. For Dyzenhaus, such connection gets transformed into a nexus between the law and the rule of law. ${ }^{37}$ Vinx affirms that if the pure theory can prove that democracy and constitutionalism, both crucial elements of legality, have inhibitory effects on iniquity, positivists who deny any internal link between legality and legitimacy will have to explain why their conception is preferable. ${ }^{38}$

\section{The Revision of the Constitutionality of the Law}

The thesis of the connection between the pure theory and Kelsen's political conception has indirect implications on the debate on which organ must be tasked with the revision of the constitutionality of legal norms. Again it is said, without giving any textual evidence, that the main concern of the pure theory is the revision of state organs' decisions. Vinx's stance is that such revision is, on the last analysis, a prerogative of the individuals subject to the legal system. ${ }^{39}$

The fact that the pure theory is a science, a function of cognition and not of will, signifies that those who are empowered to issue norms cannot also have the authority to decide whether an alleged act of promulgation objectively complies with the relevant powerconferring rules, ${ }^{40}$ or we are before acts liable to nullity as those of the imposter Hauptmann von Köpenick. The argument is that it is senseless to think that the authority can preempt judgements of attribution since 'any claim to deference presupposes that those who make the claim have already been identified as organs of the state ${ }^{\prime 41}$.

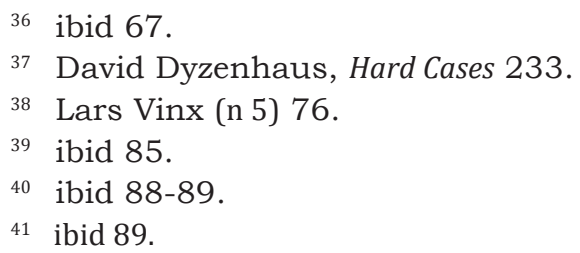


Before this identification takes place citizens do not have any obligation to obedience.

Judgements about whether an authoritative act is legal have two stages: the identification of the empowered organ and the verification that the power-conferring rules have been comply with. By default, these judgements have to be made by those to whom the act is addressed, since the act itself cannot testify to its own legality. Therefore, the testimony can only come from an external point of view, that of each particular citizen.

But, are really those subject to the positive legal system the ones who proffer the judgements of attribution? Vinx says that, for Kelsen, the 'description of the point of view of the law-abiding citizen should be willing to accept a partial transfer of his power of primary review to adjudicative institutions authorized to scrutinize the legality of acts of enactment'. ${ }^{42}$ In a fully-developed legal order, the voidability of norms replaces citizens' judgements of nullity. ${ }^{43}$ In this scenario, the original choice they face between attributing legality to norms or declaring their nullity disappears and the voidability principle enters the scene, which means that legally defective decisions can be appealed and independent courts should decide on their legal status. These organs are the most effective mean to prove the compromise of a state with the legality principle. ${ }^{44}$ Vinx points out that:

If both the citizen and the official or public agency appeal to a notion of objective legality, Kelsen assumes, they cannot coherently reject the idea of impartial arbitration of disputes over the meaning of that notion with respect to a particular dispute. It would be pragmatically inconsistent, Kelsen at times suggests, for the parties to a dispute to adopt the view that legality matters and to reject the idea that the objective meaning of one's legal rights and duties is legitimately determinable by independent courts. ${ }^{45}$ 
Thus, the task of a constitutional court is to supervise the legal legitimacy of the decisions of state organs. This can only be achieved by the full realization of the principle of legality and of democracy. ${ }^{46}$

\section{Democracy and Autocracy}

For Kelsen, democracy and autocracy are methods of norm creation. ${ }^{47}$ With this in mind I will analyze the argument Vinx elaborates, based on his reading of the Kelsenian thesis of the identity between law and state, to hold that democracy is a system that legitimizes the law. This justification of the legal order is twofold: on the one hand, representative democracy is the political system that best accords with the individuals' autonomy and freedom, since they participate in the creation of those norms that regulate their conduct. This makes easier to carry the torment of heteronomy, that is, the oppression of being governed by norms of conduct created by others. On the other hand, the norms of a democratic order are legitimate to the extent that there are formal and content dispositions that rule their creation. These dispositions prevent the arbitrariness of authorities and guarantee that the citizens' basic rights and freedoms are beyond the scope of the state organs. Only a democratic constitution has the capacity to fulfill this task: 'According to Kelsen, there is no way to understand democracy as it actually exists as an intrinsically meaningful institution unless we accept this description of democracy's essential purpose."48 Thus, by means of the citizens' indirect participation in the creation of norms, democracy guarantees that their freedom will never be subject to irrational restrictions, ${ }^{49}$ which legitimizes democratic decisions, especially those whose 'substantive rationality' is doubtful. ${ }^{50}$

46 ibid 171.

47 Hans Kelsen, Esencia y valor de la democracia (first published in German 1929, trans. by J. L. Requejo Pagés, Comares 2002).

48 Lars Vinx (n 5) 102.

49 ibid 123.

50 ibid 112. 
In Vinx's opinion, the Kelsenian concept of law stresses that the central objective of a legal order is to make sure that the political decisions that meet their content and procedural requisites, are legitimate even when citizens do not accord with their moral quality. In his interpretation of Kelsen's political ideas, Vinx emphasizes that the discrepancy among the members of modern societies on a whole range of issues generates problems of legitimacy that cannot be resolved by simply empowering an organ to decide disagreements unilaterally. It is also crucial that citizens respect each other's opinions. This duty of mutual respect derives from a fallibilist stance, characteristic of democracy, for which the different points of view about the moral quality of legal norms cannot pretend unconditional validity. For this reason, democracy is the best form of government because it is the only one that promotes such duty. At the same time it discourages epistemic abstinence by promoting individuals to defend their moral opinions openly and publicly. ${ }^{51}$

In his reading of the pure theory, democracy is, for Vinx, a rational mechanism to incorporate into positive law the irrational values that come from ethics and politics. Within this mechanism the conflicting interests can be ordered in two ways: giving preference to some or trying to strike a balanced between them. Democracy facilitates this equilibrium and, by setting procedural and content limits to the expression of the different interests, represents the rational response to their irrationality. In this way, the violence characteristic of politics is tamed and tolerance is encouraged. The weakness of Kelsen's explanation of the normativity of law is its refusal to ground the pure theory on political values. Vinx criticizes Kelsen's scientific conception because it is counterintuitive, that is, contrary to our usual understanding of the law, where legal normativity is bound to ethics and politics.

Vinx recognizes that, for Kelsen, the difference between democracy and autocracy is a matter of degree. Both methods of law creation are distinguished by the number of individuals subject to the legal order that participate in such processes. But then, it is concluded, for Kelsen every state, including those totalitarians, has some 
legitimacy, since its acts are divided into phases that go all the way down the hierarchical structure of the legal order ${ }^{52}$ In this sense, the morally wicked norms of a totalitarian state would generate a duty of obedience similar to the norms of a full-fledged democracy, given that those dispositions have also been enacted by competent organs according to an established procedure. Vinx admits that, for Kelsen, all legal systems limit political power. For this reason, legality has always a legitimizing force and the moral flaws of the law are attributable to its lack of development. The elements of legality that are present in every legal system, as weak as they might be, can be enhanced to give it full legitimacy. In consequence, the duty of obedience to the law is relative to the level of acceptance of the legal order. $^{53}$

Vinx rightly points out that the Kelsenian conception of democracy has a relativistic character given that it does not involve the normative thesis that democracy represents an absolute political value. This conception is only related to the idea that there is an internal relation between democracy and the ideal of freedom as selfdetermination, so that this ideal can only be carried out within democratic systems. According to Vinx, whether democracy is preferable to autocracy because it is a superior method for norm creation is something that cannot be scientifically proved. In Kelsen's theory, if we assume that political freedom is the supreme social value, then it can be said that democracy is the best form of government. But this ethical and political preeminence cannot be demonstrated by the science of law. ${ }^{54}$

In Vinx's reading, the thesis about the identity of law and state signifies that an act is attributable to the state only if it is legal. However, 'a judgement of attribution is not itself an exercise of legal authority but rather an exercise of jurisprudential or legal scientific understanding. ${ }^{55}$ According to Vinx, those entitled to make such judgments are the ones subject to the norm. Therefore, before we

\footnotetext{
52 ibid 72.

53 ibid 75.

54 ibid 137-138.

55 ibid 87.
} 
can say of a legal norm that it is binding, individuals subject to the legal order should determine, firstly, whether the state organs involved in the enactment of the norm are dully authorized and, secondly, whether the dispositions that rule their actions were properly followed. If citizens could not make these judgements of attribution they would have to assume that state acts have only a subjective sense, with the consequence that the alleged legal norms would be null.

Thus, it is affirmed that the identity between law and state is not, pace Kelsen, an empty conceptual truth but expresses the normative ideal that governs the exercise of public power. If the legality of acts of state is the source of their legitimacy, state organs cannot have the last word about their sphere of competence. Their acts should be opened to public scrutiny before we can attribute legality to them. In well-developed democracies this citizens' primary power of revision is deferred to independent judicial organs, which perform such scrutiny in the name of those subject to the legal order. In this way, legal norms are voidable by the revisory organs. Their voidability no longer depends on the primary judgements of attribution but on other norms that can derogate them. ${ }^{56}$

If autocracies are primitive legal orders, the identity thesis is also applicable to them. This poses some problems to the idea that democracy makes a unique contribution to the utopia of legality, since the autocratic state cannot act illegally. Within autocratic systems, the identity between law and state leads us to deny legality to all those norms whose constraining powers state organs can ignore. A norm that confers restricted authority but that does not constitute a ground to invalidate decisions in conflict with it or to punish the responsible organ 'cannot have the full force of law because it does not bind those it purports to authorize. But this means, according to Kelsen, that those who are purportedly authorized by such an unenforceable norm cannot appeal to it to defend their claim to authority.'57

The pure theory, according to Vinx, is not neutral because its explanation of legal normativity is bound to an understanding of the

56 ibid 93.

57 ibid 211. 
law according to which legal norms have a mediating role and set limits to power. This theory is adequate to the rule of law because it facilitates the transition from autocracy to this ideal. Vinx believes there is a tension between Kelsen's purpose of providing a general descriptive theory of law and the normative implications of his idea of legal objectivity. From the point of view of such theory, given that autocratic systems are also legal orders, they possess, to a certain extent, justified normativity, in spite of the fact that they impose weak constraints on political power. According to Vinx, Kelsen tries to overcome this problem by interpreting autocratic systems 'as anticipations of a legal order that more fully realizes the ideal of the rule of law'. ${ }^{58}$ He seems to ground this thesis on Kelsen's idea that, given the insufficiency of their de jure legitimacy, 'autocratic states always... have to refer to ideological sources of legitimacy external to the law in order to fully justify their claims to obedience. ${ }^{59}$

\section{The Scientific Character of the Pure Theory}

In his alternative interpretation, Vinx is not at all clear about his stance on the alleged scientific character of the pure theory. For Kelsen, he says, the pure theory is scientific as long as it is not an ideology, which is defined as a system of false beliefs that stabilizes the illegitimate relations of authority and prevents individuals from autonomously deciding how to act. Thus, the pure theory liberates us from ideological explanations of law and becomes a preparatory social critique for the moral evaluation of unjust law. In this way, the authoritarian political structures are diminished because the ideological support that such systems get from the doctrine of natural law is unmasked. To paraphrase Bernard Williams, it is affirmed that the pure theory serves the ideal of finding a stable and decent human community that depends, minimally, on mythological explanations. ${ }^{60}$

\footnotetext{
58 ibid 212.

59 Loc.Cit.

60 ibid 14-15.
} 
In Vinx's opinion, the Kelsenian exegesis of legal normativity is a non-evaluative scientific conceptual framework because, according to Kelsen, the choice between constitutionalism and autocracy is not objectively decidable, nor the identification between law and state is preferable to dualism because the former is more adequate to the ideal of the rule of law. Kelsen thinks that there are enough scientific reasons to opt for the pure theory, independent of its suitability for this ideal. ${ }^{61}$

However, Vinx criticizes the Kelsenian scientific aspirations since they are grounded on a petitio principi. The demand that legal theory be scientific and independent from other disciplines can be an operative methodological principle once its object of study has been characterized and, based on that, it is concluded that it requires an autonomous science. Contrariwise, Kelsen holds that the law is what the pure theory affirms it to be, given that all the other forms of conceiving the law are wrong because they fail to treat it as the object of an autonomous discipline. In this way we would not have an argument but a petitio principi. ${ }^{62}$ The problem is that Kelsen cannot appeal, in his defense, to an accepted conception of normative science simply because there is none..$^{63}$

What does it mean that the science of law is autonomous? For Vinx, this thesis includes three distinctive features:

1) It is a normative science and - for this reason- independent from any natural science.

2) It should be distinguished from theories of justice.

3) It is a general theory of law that describes a common structure to all legal systems. ${ }^{64}$

The conclusion is that since there is not an accepted conception of normative science, instead of trying to make sense of the thesis that the science of law would not be scientific if it were impure, the

62 ibid 29.

63 ibid 31.

64 ibid 30. 
relevant question is whether there are convincing and independent reasons to accept that the former three distinctive features are conditions of adequacy that a legal theory must satisfy. In this way, the double purity postulate with respect to empirical social sciences and substantive theories of justice (points 1 and 2 above), has any sense only if we hold that legal science presupposes the existence of autonomous values of legality. ${ }^{65}$

Vinx accepts the requisites of autonomy, independence and purity that Kelsen imposes on any legal theory, but he gives them a sense that deviates from the original. The requirement is still to prevent the introduction, into legal science, of elements from the natural or the moral world. Or in Vinx's terms, to stay away from ideological groundings that explain the law appealing to social facts and from substantive accounts that make use of theories of justice to argue that an explanation is preferable because it materializes superior moral principles. But this purity postulate does not emerge from methodological reason alone, it aims to eradicate the obstacles that stand in the way to the utopia of legality.

\section{Some Considerations on VinX's READING OF KELSEN}

One of the pillars of the thesis that the value of the pure theory is its connection with Kelsen's political philosophy is the idea that its explanation of legal normativity is not viable. On occasions, Vinx just discards this exegesis without further reasons. The only serious critique is that, as we have already seen, at the bottom of Kelsen's argument there lies a petitio principi.

Let's examine this point. It has been argued that the basic disagreements in the science of law originate from the lack of consensus about the nature of law. There are many different intuitions about its object of study that give raise to conflicting descriptive theories. So it is possible to reject any theory arguing that what it describes is not really law. To this respect, Dan Priel points out that each philosopher will be inclined to adopt the methodology that best accords

65 ibid 31. 
with his preconceptions. The main reason of such disagreements is that the fundamental methodological choice is subjective. ${ }^{66}$ The apparent consequence is that there is no way to rationally select between alternative legal theories. In this sense, it can also be held that the ideals of value neutrality, objectivity, conceptual economy, systematicity, logical consistency and methodological unity, which are characteristic of modern science, are not essential features of legal theory or do not determine, by themselves alone, what the law is, since they are compatible with different types of legal theory.

The idea that we must firstly know what the law is in order to determine what type of explanation it requires, is based on a previous decision about whether it is the theory or the practice which establishes the meaning of legal concepts. To hold that it is the latter that fixes such meaning involves a kind of Wittgensteinian thesis for which meaning is use. So we have first to describe what people do and say when they use legal concepts in order to, a posteriori, arrive at a conception of law that suits this practice. The alternative a priori way to proceed is to define firstly what a legal order is based on certain principles or categories. These are two criteria of identification: social facts $v s$ a priori categories.

The first alternative revolves around the idea that human actions have in themselves a meaning that is not the product of a conceptual framework but can be discovered through careful observation. If we observe the actions of lawyers, legislators, judges and other participants in the language game of law, we can figure out what a norm, a sanction, an obligation or an empowerment is. But, do our actions really have a legal meaning that does not refer to any conceptual scheme but inheres in such acts which anyone who takes part in this language game can read? Does it make sense to say that social facts carry with them their own interpretation?

This idea is wrong-headed because among human acts qua physical phenomena there are causal relations but not legal relations. In order for the deliberation among a group of people can be interpreted as a session of Parliament, or the signature of some documents as the subscription of a contract, we need a normative con-

66 Dan Priel, 'Jurisprudential Disagreements and Descriptivism', 8 Problema. 
ceptual framework that makes possible the attribution of legal meaning to such acts. Therefore, the sole social practice of law cannot be the source of the meaning of legal concepts. In this way, for example, it can be said that a Dworkinian-oriented legislator would probably conceive her task as the creation of exclusionary reasons for action, while a Kelsenian-inclined legislator might see her own work as the imputation, to certain acts, of legal consequences. In both cases the attribution of meaning does not take place in theoretical isolation, but within a conceptual framework.

On the other hand, to hold that it is the theory that fixes the meaning of legal language faces the problem that there is not a unique explanation and we do not seem to have a criterion to demonstrate the superiority of one of them. The way out to this apparent blind alley is to pick the theoretical framework best suited to explain the widest range of legal phenomena. This involves a conception according to which science gets justified by the systematic, coherent, objective, and value neutral results it is able to deliver. Thereby, given our ideal of science, the descriptive-explanatory character of legal science should be upheld.

Vinx's reasons to reject the autonomy of the pure theory are weak, so they do not constitute a knockdown argument. The alleged petitio principi Kelsen commits when explaining the law is real only if we have previously assumed that the adequate method for a science is established after careful observation of its object of study. However, this idea implies a kind of naïve epistemological realism. From this perspective, cognition involves a passive observer that gets in contact with an object that is wholly construed prior to any relation with him. The observer, as it were, reproduces the intrinsic nature of the object since he must focus to reflect in concepts the traits of a reality independent from him. This entails the implausible idea that human acts have a legal meaning not relative to any conceptual framework. For these reasons, the thesis that the science of law epistemologically construes the law using a priori concepts describes more accurately its task.

If this is so, the autonomy of the science of law is a value that should be pursued regardless whether it contributes to the realization of the utopia of legality. One could dismiss the pure theory be- 
cause an alternative framework better explains, say in a more systematic fashion, some theoretical problems, but it would be senseless to reject it on the ground that the rival theory is more conducive to the utopia of legality. The realization of this ideal, commendable as it is, cannot be justified from the point of view of legal science. The Kelsenian double purity postulate serves to demarcate the law as an object of scientific enquiry. This aim is independent from the practical consequences that this postulate might have.

We are before what can be called a categorial error. The science of law should be evaluated by internal criteria, so that its merit will depend on how it fares in explaining and describing the law. Thereby, it is mistaken to judge it using political standards such as its contribution to a desirable state of affairs, since neither ideals define the nature of a discipline nor the science of law is a mean to obtain certain goals.

Now I want to refer to the idea that legality legitimizes the acts of the state in so far as it keeps alive the hope for the utopia of legality. I think this idea brings with it a certain degree of discretionality. No doubt, citizens' judgements about whether the legislative, administrative or judicial decisions within a legal order advance in the direction of the rule of law are influenced by a range of moral, political and ideological opinions that express different evaluations about how close a legal order is from the rule of law. How it is possible, from this multiplicity of moral standpoints, to arrive at a reasonable and general hope in the utopia of legality is something that escapes us.

This element of discretionality gets manifested the moment those who are subject to the legal order ponder its degree of legitimacy or its proximity to the utopia of legality, which could turn out to be insufficient to compensate the substantive moral reasons these individuals may have for not following the law. It is said that, according to the pure theory, someone not willing to give any obligatory force to the fact that a certain norm has been legally enacted, would be acting without a moral justification. He would be expressing his 'unwillingness to subject his normative conflicts with others to legal arbitration'. ${ }^{67}$ The problem with this thesis, apart from being mis-

67 Lars Vinx (n 5) 74. 
taken to attribute it to Kelsen, is that in a morally wicked legal order, such as the Third Reicht or the Apartheid, Jews and black people would have moral reasons for not giving to its norms the slightest degree of legitimacy, notwithstanding its constitutional correctness. ${ }^{68}$

The idea that the legality of a norm depends on the citizen-judgement of attribution about its legitimacy is based on an alleged principle according to which those subject to the legal order, to whom obedience is demanded, should decide whether the norm is attributable to the state, that is, whether it is valid. Another way to put it is to say that it would be morally incorrect to deprive of this prerogative to those who are subject to the norms and are claimed obedience.

However, in order for such a moral principle to be operative it will be necessary to legally introduce it through an act empowering citizens to issue such judgements. Unless there is such an act, we would have an empowering norm without an act of authorization, contrary to the positivist dictum: keine Imperativ ohne Imperator. In this way, political or moral correction is thought to have the power to create law. Besides, as we will shortly see, this contradicts Vinx's idea that the attribution of a norm to the state is the task of the science of law, since, for him, such attribution is not a result of the conceptual identity between law and state, but the outcome of individual acts of will psychologically explainable and grounded on a moral principle. The problem is that as long as it remains a mystery how morality can produce legal norms without an act of promulgation, the alleged citizens' right to make those judgements hangs in the air. It is worth noting that Vinx justifies the revision of norms by a constitutional court arguing that citizens defer their right of primary revision to an adjudicative organ. However, such right cannot be deferred if it has not been yet grounded.

There are two ideas in Vinx's conception of the Kelsenian legal science that worth some scrutiny. The first one is that the main preoccupation of the pure theory is the revision of state acts, and that the citizens' right to evaluate their legality has a scientific grounding.

68 For a recent discussion on the legality of morally wicked legal systems see David, Dyzenhaus, Hard Cases, 
That the analysis of the constitutionality of norms cannot be an aim, let alone the principal one, of the science of law is clear if we reflect on the fact that the justification of a particular institutional design is not an explicative endeavor. In any case, it is the task of legal policy to show that such design is the most effective mean to achieve certain purposes. In this way, the alleged connection between the pure theory and Kelsen's political philosophy ends up dissolving the frontiers between the science of law and the design of political institutions.

The second idea implies the thesis that the science of law makes the law, since the citizens' right to make judgements of attribution of legality is said to be a scientific truth and not the result of an act of will. Mysteriously, the science of law is turned into a lawmaking authority. Moreover, this contradicts the idea that such right emanates from an alleged moral principle, according to which those to whom obedience is demanded should be the ones who judge the adequacy of norms to their material and procedural standards. Oddly enough, we would end up here with a right that comes, at the same time, from scientific considerations and from a moral argument.

Now I will come back to Vinx's idea that autocracies used to lean on ideological justifications. For Kelsen, these legitimizing discourses, which also happen in democracies though in a lesser extent, pretend to turn moral or political relative values into absolute ones. They have nothing to do with the scientific characterization of the law. Legal science preserves its character as long as it is not an ideology. In this sense, an autocracy is not a rudimentary legal order whose restrictions on political power are so insufficient not to require ideological justifications. According to Kelsen, what makes possible the legal interpretation of the acts of, say a dictator, is not the kind of discourse employed by his supporters to legitimize him, but the presupposition of a basic norm, that is, a theoretical and not a political act. Representative democracy has been historically associated with the restrictions on political power characteristic of the liberal tradition. However, it is a methodological syncretism to introduce such relation into the legal definition of democracy.

It is possible to conceive, without contradiction, a totalitarian state that limited the dictator's power, for example by delegating certain state functions to body of experts, even though there would 
not be any historic reason to expect this to happen. Though Kelsen associates the autocrat with a solipsistic character, a strong will to power and an absolutist ethico-philosophical conception, it is logically possible that such autocrat imposed himself restrictions. We would then be before a pragmatic inconsistency, but as Kelsen warns us:

But just because it is within the soul of the empirical human being and not within a sphere of pure reason that politics and philosophy originate, we must not expect that a definite political view will always and everywhere be combined with the philosophical system which logically corresponds to it. ${ }^{69}$

From a theoretical point of view it cannot be affirmed that autocracy is an inferior system of government whose gradual development leads to democracy, since the science of law does not politically or morally evaluate legal orders. This thesis can only be defended if it is assumed that the values commonly associated with democracy are better that those linked to autocracy. But such justification requires an ordering of values that falls into the realm of politics or ethics. Kelsen asserted that the point of view of the science of law can only establish which means are better suited to bring about certain ends, but not which ends must be pursued. 'For the relationship between means and end is a relationship between cause and effect, objectively ascertainable by science, whereas the recognition of an end as an ultimate value, which is itself not the means for a further end, lies beyond scientific cognition' ${ }^{70}$

Lastly, let's take another look at Vinx's thesis that to presuppose a basic norm amounts to postulating that exercises of coercive force under its authorization are morally justified. It has been suggested that this idea can be conceived as a kind of Alexian argument which would run as follows: the official saying someone "I coerce you to do this inmoral thing" will be incurring in a pragmatic contradiction as does the person affirming "the cat is on the mat but I do not believe it". Contrary to what happens in the latter case, where the statement of a state of affairs pragmatically implies the belief in it, in the for-

69 Hans Kelsen, 'Foundations of Democracy', 15.

70 ibid 40. 
mer the acts of coercion do not entail by themselves that they have to be morally justified but only, as long as we presuppose the basic norm, that officials are empowered to coerce. In order to introduce the moral predicate as a necessary element of the exercises of coercive force we would have to move away from Kelsen and to assume, for example, in Hartian terms, that the rule of recognition necessarily incorporates moral principles, but the exploration of this possibility would take us far beyond the scope of this paper. It has also been pointed out to me that Dyzenhaus has expressed that the ground of the revisionary reading of Kelsen is the political notion of personhood taken from Roman Law. Thereby, inasmuch as persons are rational, the legal regulations of their conducts have to appeal to legitimacy. Though personhood remains a legal concept, it opens the door for legitimacy in that it presupposes rationality, which brings with it a minimum of moral content. ${ }^{71}$ This would seem to give room to the ideal of the rule of law or to some sort of Fullerian legal internal morality. In this case we would be before formal demands that law needs ideally to fulfill, but they would not demand acts of coercive force to meet certain legally independent moral standards.

\section{CONCLUSions}

Throughout this paper it was established that Vinx's criticism of Kelsen's explanation of legal normativity along with its purity principle, is weak and does not represent a knock-out argument against it. In consequence, there are no reasons to hold that the pure theory lacks any intrinsic value as an explanation of law and that its usefulness consists in that it facilitates the utopia of legality. We should keep in mind that Vinx aims at a political reevaluation of the pure theory. The reason is that the epistemological self-comprehension of the pure theory, as an effort directed to providing the science of law with the conceptual framework to determine its object of study, is implausible. However, as I have said, Vinx does not provide convincing reasons to support his stance. With the exception of the doc-

71 I want to thank one of my anonymous referees for both suggestions. 
trine of natural law, he does not either demonstrate why the pure theory is more adequate to the rule of law than other alternative explanations of legal normativity.

It could be said that Vinx's argument is designed to go against the "descriptive" or "external" view of Kelsen's endeavor, and that it should be read as offering a "scientific" doctrinal account from the Hartian "internal point of view", i.e. one that takes into account the views of the officials of a legal system. In this sense, many of Vinx's arguments could be taken to suggest that the standard interpretation is mistaken because it puts the legal theorist in the place of the sociologist (Hart's "external point of view") and not in the vantage point of the lawyer; but once we make the correction the link between the law and some political values become evident and coherent. ${ }^{72}$ My answer to this suggestion would be that, for Kelsen, the description of the norms of a legal order made by the jurist is of a different kind from the sociologist's. In the former case it presupposes a series of concepts that allows the legal reading of human acts, so that she is able to describe the normative connections between illicits and sanctions, within the system, using the principle of imputation. Whereas in the latter case the sociological description has other aims, for example, to identify types of political leadership or the prudential reasons behind the efficacy of a legal system; consequently, the theorist employs a different set of notions. However, as Kelsen says, the sociologist, in describing the kind of relations she is interested in, inevitably makes use of legal notions like that of norm, obligation, sanction and so on.

On the other hand, I think it is inaccurate to ascribe to Kelsen a Hartian "internal point of view", since the idea that the normativity of law can only be grasped if we adopt the perspective of those who consider the norms of the system they live in as guides for their conduct, is wholly alien to the epistemological framework of the pure theory. Kelsen rejects the idea of introducing a sociological method within the legal science because, as a description of social events in terms of causes and effects, sociology is a science based on a naturalistic approach. Nevertheless, this does not entail that

72 I owe this suggestion to one of anonymous referees. 
Kelsen embraces the internal stance officials take when establishing what counts as valid law. As we know from Hart, the recognition of the legal sources in a certain community is founded on the agreement, among all those who take part in legal affairs, about what is the valid law in a given system. If we want to phrase Kelsen's position in terms of perspectives, it can be affirmed that the jurist has to adopt the point of view of legal science, that is, its epistemological framework, in order to describe the norms of an order. This standpoint has nothing to do with a social recognition in that the latter falls within the domain of sociology. As Kelsen holds, if we take a naturalistic or sociological stance we simply lose track of the normativity of law.

It is worth noting the conception of democracy on the basis of which Vinx construes his non-standard interpretation of Kelsen is substantially robust, given that it includes freedoms, rights and mechanisms for the revision of the constitutionality of legal norms. All these elements, as politically and morally commendable as they might be, do not form part of Kelsen's characterization of democracy as a method for the creation of legal norms. So, to the extent that Vinx wants to fix a nexus between the pure theory and Kelsen's political ideas, it can be pointed out that his proposal is ridden with doctrinal inaccuracies.

As we saw, it is conceptually possible to think of an autocracy where the utopia of legality was fully realized. Thus, for this task democracy does not have a theoretically superior vantage point, though it has been historically the most efficient form of government to achieve this goal. We have here a methodological error that consists in confusing the nature of a phenomenon, say democracy, with its political value. The same mistake occurs, Kelsen states, when the concept of democratic representation is not distinguished from the contribution democracy makes to the existence of the state. ${ }^{73}$

The necessary relation that Vinx seeks to establish between legality and legitimacy mixes the nature of law with the aims particular

73 A similar confusion arises between the essence of democratic representation and the conditions under which democracy can prosper. Hans Kelsen, "Foundations of Democracy" 9-10. 
legal orders may pursue. Democracy and the utopia of legality can only have a means/end relation. However, to prove that a certain mean is the best way to bring about a goal is not a task for the science of law but, in any case, for legal policy. To this respect, it is interesting to point out Kelsen's hesitant attitude, which Dyzenhaus stresses, when he tries to clear his mind about the restrictions that should be imposed on political power for the realization of the rule of law, since he either refrains from the attempt or ends up admitting that the debate on these limitations is political and not a matter for the science of law. ${ }^{74}$

We indicated that Vinx commits a series of interpretative mistakes such as confusing, in his reading of the role of the basic norm in the explanation of legal normativity, theoretical acts with acts of will; or identifying the attribution of legality to state acts, which is the theoretical product of the identity between law and state, with the conformity of the subjects to the legal order. At the bottom of these errors lies the idea that the value of the pure theory resides in its relation with Kelsen's political philosophy. So, the question we should ask is whether this political interpretation of Kelsen is sound. We have already stated that Vinx's reasons against Kelsen's own interpretation of his work are weak. A good example is when he attacks such reading saying that it is counterintuitive and contrary to our common way of understanding law. It could be said that the adequacy of a theory to the way its object of study is usually conceived is not a scientific criterion to evaluate it. The pure theory is to be upheld or abandoned on the basis of criteria that would apply to any explanation that aims to be scientific. If the pure theory contributes to the realization of a social and political system, though relevant from a political and moral point of view, lacks any importance for its epistemological or scientific status.

Now we have to ask whether there exists any relation between the pure theory and Kelsen's political philosophy. Once the idea of a necessary connection has been dismissed, the most convincing alternative is that we are before a pragmatic nexus. Thus, the scientific character of the science of law is consistent with Kelsen's prefer-

74 David Dyzenhaus, "Legal Theory in the Collapse of Weimar" 128-129. 
ence for democracy and the means to make it more effective: political rights, freedom of speech, tolerance, the rule of law, among others. ${ }^{75}$ Nevertheless, there is not a logical contradiction in supposing a democracy within a context of restrictions to freedoms and rights, surrounded by individuals with a strong will of power, since democracy is, from a legal point of view, a method for the creation of law. In any case, what we have here is a pragmatic inconsistency like the one, pointed out by Anna Pintore, that would commit someone who favored democracy but rejected relativism or stated that it is raining bur he does not believe it. ${ }^{76}$

Confusing science with politics, as Kelsen warned in his debate with Carl Schmitt, can lead to the illusion of giving a scientific justification to what are only relative political goals. The tendency to bind science with politics in order to graft onto the latter the prestige of science, Kelsen concluded, can bring to the former harmful consequences, even when such binding is carried out with the best intentions as to defend a morally good cause, given that the value of the science of law is intrinsic to it and distinct from the political or moral merits of a certain social system. ${ }^{77}$

What is then the relation between the science of law, democracy, the rule of law and the principle of legality? According to the NeoKantian/transcendental spirit of the pure theory, democracy, from a nomo-dynamic point of view, is a method for the creation of legal norms. The rule of law and the principle of legality are means for what Kelsen calls the rationalization process that democracy carries out: the tendency to subject the acts of the state to pre-established general norms, generally written and promulgated, created through well-organized processes, which regulate such acts in detail as to make them predictable and reduce the degree of discretionary power of public officials. It is worth stressing that this is a tendency and not an intrinsic element of the legal definition of democracy.

75 Hans Kelsen, "Foundations of Democracy".

76 Anna Pintore, 'Democracia sin derechos: En torno al Kelsen democrático', 23 Doxa 121-122.

77 Hans Kelsen, ¿Quién debe ser el defensor de la constitución? (first published in German 1931, trans. R.J Brie, Tecnos 1995) 81-82. 
In this sense, the principle of legality, which demands that state acts be in conformity with the general dispositions that rule them, contributes to legal certainty and to the predictability of legal norms, which are the ideal features of a democracy vis a vis the discretionality of autocratic systems. The latter seek in the exception of the individual case, opposed to the general law, or as Kelsen puts it, in the creative Kairós ${ }^{78}$ or in the spur of the moment inspiration, in the free and intuitive creation before any new circumstance, an alleged absolute justice. This justice is not expressed in general norms because they cannot contain what really matters, 'the pulse of life'. On the contrary, absolute justice gets manifested in each individual case since it has the virtue to fit into their particularities. This is the reason why the legislation, within the ideology of democracy, is considered to be the basis of the other functions of the state. ${ }^{79}$

Thus, the science of law maintains its autonomy with respect to the conditions (rights and freedoms), and the means (protections of minorities, independent revisory bodies and general legal norms), that allows democracy to contribute more effectively to the stability of political systems. In passing, it is worth noting that Dyzenhaus mistakenly believes that the principle of legality emerges when we adopt a scientific perspective, thereby confusing a technical mean for certain aims with an essential feature of democracy. Though he also contradictorily affirms that by means of such principle liberal democracy is warranted, which is indicative of its instrumental character ${ }^{80}$ To conclude, between the science of law and representative democracy there is a conceptual/explicative relation, since the latter is legally defined as an ideal method for the creation of norms, which has been historically realized in various degrees but always has barred, for different reasons, some groups of individual from political participation. On the other hand, between democracy, the rule of law and the principle of legality, there is a connection of means to

78 In ancient Greek mythology, Kairós was the God of the 'fleeting moment' and had a qualitative nature opposed to that of Cronos which was quantitative.

79 Hans Kelsen, 'Foundations of Democracy' 29; Hans, Kelsen, “Forma de estado y vision del mundo" 251-253.

80 David Dyzenhaus, Legality and Legitimacy 153. 
ends, given that through the rule of law and the principle of legality democracy rationalizes the regulation of human conducts.

\section{REFERENCES}

Bulygin E., 'An Antinomy in Kelsen's Pure Theory of Law', 3 Ratio Juris.

Cohen H., Logik der reinen Erkenntnis (Bruno Cassirer Verlag 1922).

Cohen H., Ethik des reinen Willens (Georg Olms Verlag 2002).

Dyzenhaus D., 'Legal Theory in the Collapse of Weimar. Contemporary Lessons?', 91 The American Political Science Review.

Dyzenhaus D., Legality and Legitimacy: Carl Schmitt, Hans Kelsen, and Hermann Heller in Weimar (Oxford University Press 1999).

Dyzenhaus D., Hard Cases in Wicked Legal Systems: Pathologies of Legality (Oxford University Press 2010).

Heidemann C., 'Die reine Rechtslehre im Lichte des kritischen Rationalismus' 18 Ratio Juris.

Kelsen H., 'Foundations of Democracy' 66,1,2 Ethics.

Kelsen H., Teoría General del Estado (first published in German 1925, trans. by L.L Lacambra, Editora Nacional 1965).

Kelsen H., 'Un inédit de Kelsen concernant ses sources kantiennes', 7 Droit et Société.

Kelsen H., Problemas capitales de la teoría jurídica. Desarrollados con base en la doctrina de la proposición jurídica (first published in German 1923, trans. by W Roces, Porrúa 1987).

Kelsen H., Quién debe ser el defensor de la Constitución? (first published in German 1931, trans. by R. J. Brie, Tecnos 1995).

Kelsen H., Pure Theory of Law (The Lawbook Exchange 2009).

Kelsen H., "Forma de estado y visión del mundo" in Oscar Correas (ed), El otro Kelsen (Coyoacán 2003).

Kelsen H., Esencia y valor de la democracia (first published in German 1929, trans. by J.L Requejo Pagés, Comares 2002). 
Kelsen H., Introduction to the Problems of Legal Theory (first published in German 1934, trans. by B. Litschewski and S. Paulson, Clarendon Press 1997).

Manero J. R. and Atienza M., Para una teoría postpositivista del derecho (Palestra-Temis 2009).

Manero J. R., "Cincuenta años después de la segunda edición de la Reine Rechtslehre. Sobre el trasfondo de la teoría pura del derecho y sobre lo que queda de ella", Doxa, 33.

Nino C., La validez del derecho (Astrea 1985).

Nino C., "Some Confusions surrounding Kelsen's Concept of Validity" in Stanley Paulson and Bonnie Litschewski (eds), Normativity and Norms. Critical Perspectives on Kelsenian Themes (Clarendon Press 1998).

Pasher M,. "Hermann Cohens Einfluss auf Kelsens reine Rechtslehre", Rechtstheorie 23, 4.

Paulson S., "Four Phases in Hans Kelsen's Legal Theory? Reflections on a Periodization", Oxford Journal of Legal Studies, 18.

Paulson S., "The Great Puzzle: Kelsen's Basic Norm” in Luís Duarte d'Almeida, John Gardner and Leslie Green (eds), Kelsen Revisited. New Essays on the Pure Theory of Law (Hart Publishing 2013).

Paulson S., "A Justified Normativity Thesis in Hans Kelsen's Theory of Law? Rejoinders to Robert Alexy and Joseph Raz" in Matthias Klatt (ed), Institutionalized Reason: The Jurisprudence of Robert Alexy (OUP 2012)

Paulson S., Facultad, responsabilidad y la teoría pura del derecho. Aspectos de una reconstrucción de acuerdo con la escuela NeoKantiana de Marburgo (Fontamara 2014).

Paulson S., 'On the Puzzle Sorrounding Hans Kelsen's Basic Norm', 13 Ratio Juris.

Pintore A., 'Democracia sin derechos. En torno al Kelsen democrático' 23 Doxa.

Priel D., 'Jurisprudential Disagreements and Descriptivism', 8 Problema. Anuario de Filosofía y Teoría del Derecho. 
Raz J., "The Purity of the Pure Theory" in Stanley Paulson and Bonnie Litschewski (eds), Normativity and Norms. Critical Perspectives on Kelsenian Themes (Clarendon Press 1998).

Raz J., "Explaining Normativity. On Rationality and the Justification of Reason" in Engaging Reason. On the Theory of Value and Action (Oxford University Press 1999).

Raz J., "Kelsen's Theory of the Basic Norm" in The Authority of Law: Essays on Law and Morality (Oxford University Press 2009).

Scarpelli U., ¿Qué es el positivismo jurídico? (first published in Italian 1965, trans. by J. Hennequin, Cajica 2001).

Schmill U., 'Algunas influencias de Hermann Cohen en Hans Kelsen', 21 Isonomia.

Vinx L., Hans Kelsen's Pure Theory of Law. Legality and Legitimacy (Oxford University Press 2007). 